Commun. Fac. Sei. Univ. Ank. Series C

V. 9. pp. 33-47 (1991)

\title{
THE CEREBRAL NEUROSECRETORY SYSTEM AND THE DIVER- SITY OF THE NEUROSECRETORY CELL TYPES IN PIMPLA TURIONELLAE L. (HYMENOPTERA: ICHNEUMONIDAE)
}

\author{
AYDIN ÖZLÜK \\ Department of Biology, Faculy of Science, Ankara University, Ankara, Turkey.
}

(Received August 6, 1991; Accepted December 3, 1991)

\section{ABSTRACT}

The anatomy and the histology of the brain and the retrocerebral endocrine glands of the adult $\boldsymbol{P}$. turionellae have been studied by staining techniques such as chrome haematoxylin phloxine, paraldehyde fuchsin and performic acid victoria blue. Three types of neurosecretory cells were observed in the brain. They were named as Type-I, Type-II and Type-III. The neurosecretory granules, which were stained dark purple with paraldeyde fuchsin, were present only in the Type-I cells. The same neurosecretory granules were also present in the nervi corporis cardiaci, the corpora cardiaca, and the corpora allata. It was thought that the neurohaemal organ was the corpora cardiaca and some of the neurosecretory material directly passed into haemolenph because of the fact that the amount of the neurosecretory material in the corpora cardiaca was never as abundant as in the nervi corporis cardiaci.

The illustrations correlated with the histology of the brain and the retrocerebral endocrine glands of the adult $P$. turionellae are presented in the paper. The different types of cell in $P$. turionellae are compared with the neurosecretory cells described in other species.

\section{INTRODUCTION}

The neuroendocrine system of the insects consists of brain, $\mathrm{CC}$, $\mathrm{CA}$, suboesophageal ganglion, thoracic and abdominal ganglions. The nerve cells with secretory activities shown by specific staining techniques (GOMORI, 1950; DOGRA and TANDAN, 1964; DELPHIN, 1966) are called "neurosecretion cell". Neurosecretory cells are identified in various parts of the central nervous system (ARVY and GABE, 1962), The neurosecretory cells are in two distinct groups in the pars intercereb- 
ralis of the protocerebrum of the brain (DOGRA, 1967). The first group is the median neurosecretory cells. This group has been the subject of many researches (HIGHNAM, 1961; STRONG, 1965a). The axons of the cells leave the median group together as two axon clusters They pass the brain transversely, cross each other in it, leave the brain as nervi corporis cardiaci and enter the anterior corpora cardiaca (STRONG, 1965a; DOGRA, 1967; PEACOCK and ANSTEE, 1977; KHAN et al., 1984). The other group is lateral neurosecretory cells. In some species this group has never been determined (THOMSEN, 1954; AWASTHI, 1973). The neurosecretory cells are also present in other parts of the brain. They are located in the ventral part and optical basement of the protocerebrum, in the deutocerebrum and in the tritocerebrum (HIGHNAM, 1961; CREDLAND and SCALES, 1976).

The neurosecretory cells are classified into various types. One of the criteria in this classification is the difference in colour of cytoplasm and granules of these cells although the same staining technique is applied (DOGRA, 1967; AWASTHI, 1976; PEACOCK and ANSTEE, 1977).

The suboesophageal ganglion is located in the ventro-posterior of the brain and connected to the brain by a pair of connectives. In some insects, these nerves are extremly short and the suboesophageal ganglion is merged into the tritocerebrum by taking the oesophagus between the brain and itself (THOMSEN, 1954; NAYAR, 1955; AWASTHI, 1973). The neurosecretory cells are also identified dorsal, ventral and lateral to ganglion (FLETCHER, 1969; CREDLAND and SCALES, 1976).

Corpora cardiaca are located ventro-posterior of the brain and the hypocerebral ganglion is just ventral to it (PEACOCK and ANSTEE, 1977). In some insects, this endocrine gland is a neurohaemal organ, storing the neurosecretory material coming from the neurosecretory cells of the brain (ARVY and GABE, 1962; FRIEDEL and LOUGHTON, 1980). Another endocrine gland connected to the corpora cardiaca is corpora allata. The corpora allata are connected to the corpora cardiaca by a pair of nerves, nervi corporis allati-I and to the suboesophageal ganglion by another pair, nervi corporis allati-II (HOFFMANN, 1970; PEACOCK and ANSTEE, 1977; ÖZLÜK, 1991).

If the literature on the neurosecretory system of the insects is examined, very few studies are seen on Hymenopterian species. The usage of Hymenoptera, which uses many parasitic Lepidopterian species 
as a host, as a biological control agent increases the importance of these species day by day (ROSEN, 1986). In this study, endoparasitic Hymenopterian species $P$. tuionellae has been studied morphologically and histologically due to the lack of studies on the cerebral neursendocrine sysiems and that the production of this species in the laboratory conditions is practice. Therefore this study could be a preliminary base for further physiological and electron microscopic researehes in this species.

\section{MATERIAL AND METHODS}

This study was carried out by using the adult males and females of $P$. turionellae. The continuity of the stock culture was maintained by feeding the larvae with great wax moth, Galleria mellenolla pupae and the adult ones with $50 \%$ honey solution and pupae. The experimental insects were kept in fenced cages in the dimensions of $25 \times 25 \times 25 \mathrm{~cm}$. after they developed from the pupae as adults. They were fed with cotton pieces with $50 \%$ honey solution placed at the base of their cage. Apart from that, every insect was given a pupae every two days in order to satisfy their host haemolenph needs. All of the photographs in the study were obtained from the paraldehyde fuchsin-stained preparates.

\section{Dissection and Histological Techniques}

The remaining parts of $\boldsymbol{P}$. turionellae, after its mouth parts, eye cutin and antennae had been cut out, were placed in a petri dish containing physiological saline solution. The cutin just above the head was cut completely by the help of sharpened tongs and dissection needles under the binocular stereomicroscope. The surrounding tissues of the brain left intact in order to obviate the separation of corpora cardiaca and corpora allata from the brain. The dissected organs were kept in Bouin's fixator for 12-18 hours and washed with $70 \%$ alchol. The paraffin'block procedures of the organs were carried out by means of the known method. In order to complete these procedures, 7 micron thick crosssections were obtained from these blocks by using the rotary microtome. These sections were stained with either paraldehyde fuchsin (GOMORI, 1941) or chrome haematoxylin phloxine (GOMORI, 1950). Apart from that, ten insects were stained with performic acid victoria blue total staining technique (DOGRA and TANDAN, 1964). The abbreviations for figures and text have been shown at the end of the Acknowledgement. 


\section{RESULTS}

The General Anatomy of the Brain and the Endocrine Glands

The brain of $\boldsymbol{P}$. turionellae consists of three parts; protocerebrum, deutocerebrum and tritocerebrum. There are two large optic lobes formed by the combination of combined eyes at the both sides of the protocerebrum. Deutocerebrum is easily distinguishable and has two big lobes closely located to each other where antennae nerves come. On the contrary, tritocerebrum is not easily distinguishable. Both the tritocerebrum and the suboseophageal ganglion surround the oesophagus completely. Since the nerve between these two parts is extremly short, they appear to be merged to each other. The joint line between these two parts is not clearly seen due to this merged situation; thus, suboesophageal ganglion appears to be a lobe of the brain (Fig. 1, 6b).

The corpora cardiaca and the corpora allata are present in the part where oesophagus enters the brain. The corpora cardiaca are elongated structures lying ventral to the brain and dorsal to the oesophagus. The

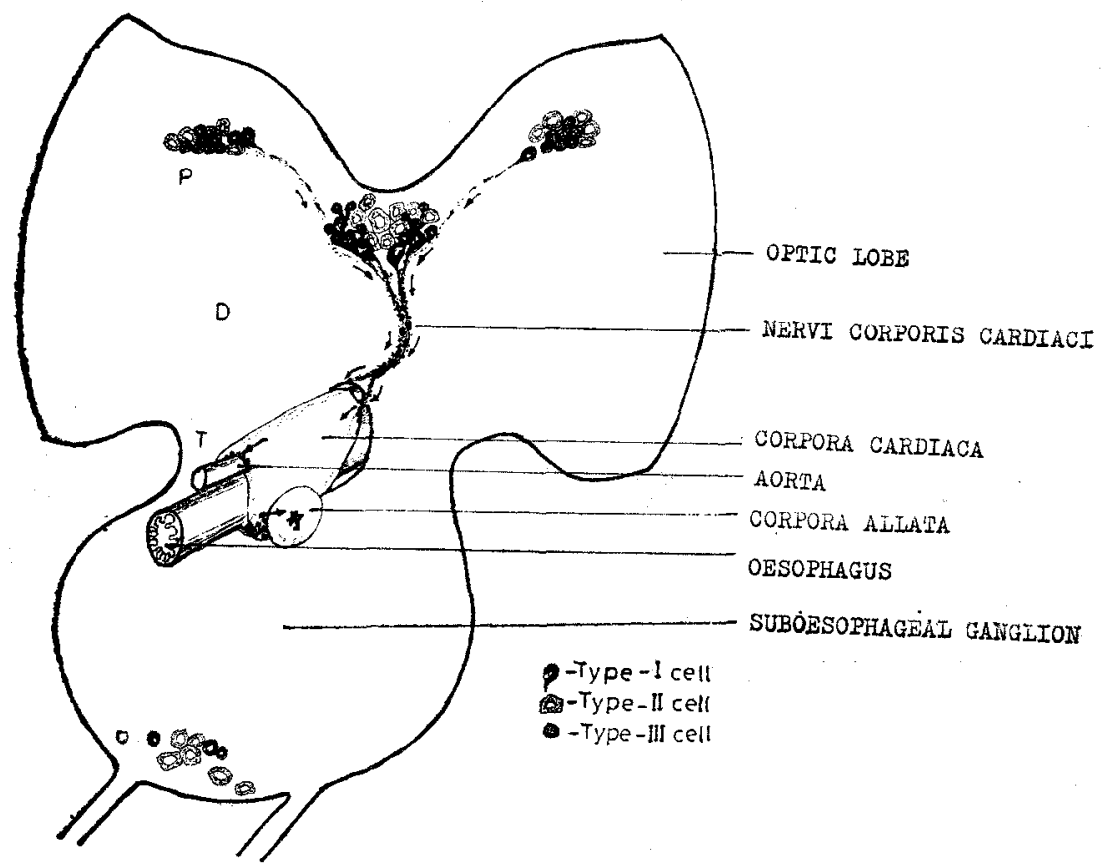

Fig. 1. A diagram of the brain, retrocerebral endocrine organs and suboesophageal ganglion showing the position of the neurosecretory cells. The arrows indicate the pathways along which neurosecretory material is transported. 
corpora cardiaca surround the aorta and the oesophagus completely (Fig. 1, 8). The nervi corporis cardiaci between the brain and the corpora cardiaca are only apparent in the histological sections because they are extremly short. The corpora allata are paired, almost spherical bodies which lie on each side, ventıo-posterior to the corpora cardiaca (Fig. 1, $3 b, 7,8)$. Their nervous connections with the corpora cardiaca are only observable in some sections (Fig. $3 b, 7,8$ ). The recurrent nerve can be seen in sections. When this nerve, located between the aorta and oesophagus, is followed, it ean be observed to become slightly thicker between the corpora cardiaca.

There obtained no satisfactory result with the total staining technique used for the determination of the neurosecretory cells and their nerve pathways in the brain. The brain tissue was stained a transparent blue colour. There are no differences between the anatomy of the males and the females.

\section{Histological Staining}

The series of sections were obtained and subjected to chrome haemotoxylin phloxine and paraldehyde fuchsin staining techniques. The latter technique was found to give better results. In the sections stained with chrome haematoxylin phloxine, the brain tissue was stained light pink and the cytoplasm of neurosecretory cells stained dark blue. Although it was possible to observe the cells had different size, the stainability of the cells showed no significant difference with this technique. On the other hand, the brain tissue was stained light green with paraldehyde fuchsin. In this staining technique, the neurosecretory cells were stained different colour and their granules became visible. These cells were divided into three different groups according to their colours and granules. These cells were called Type-I, Type-II and Type-III neurosecretory cells.

\section{Type-I Neurosecretory Cells}

This type of cells were readily observable in sections because their cytoplasm was stained light purple and their granules were stained dark purple with paraldehyde fuchsin. The density of granules in the cytoplasm varied among the adjacent cells so much so that it could be observed even homogenous purple coloured cells whose cytoplasm were filled completely with granules. There were 12-16 cells and they were observed in the pars intercerebralis of the protocerebrum (Fig. 2a, 6a). In addition to these, there were one or two cells in the lateral of the protocerebrum 
(Fig. $2 \mathrm{~b}, 3 \mathrm{a}$ ) and two or three cells in the ventral of the suboesophageal ganglion (Fig. 2c, 3b).

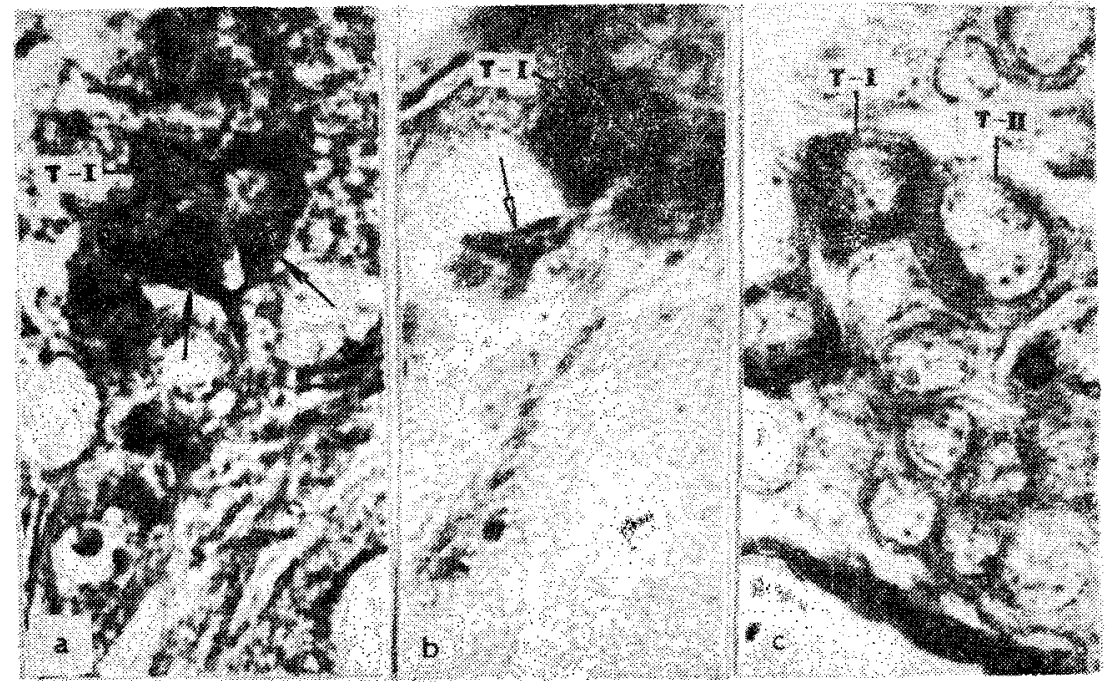

Fig. 2. Type-I neurosecretory cells in the pars intercerebralis (a), lateral (b) of the protocerebrum and in the ventral of the suboesophageal gangiion (c). Note the axonal position of the neurosecretory material in the cells $(\rightarrow)$ and discharge of the neurosecretory material $(\rightarrow) .250 \mathrm{x}$.

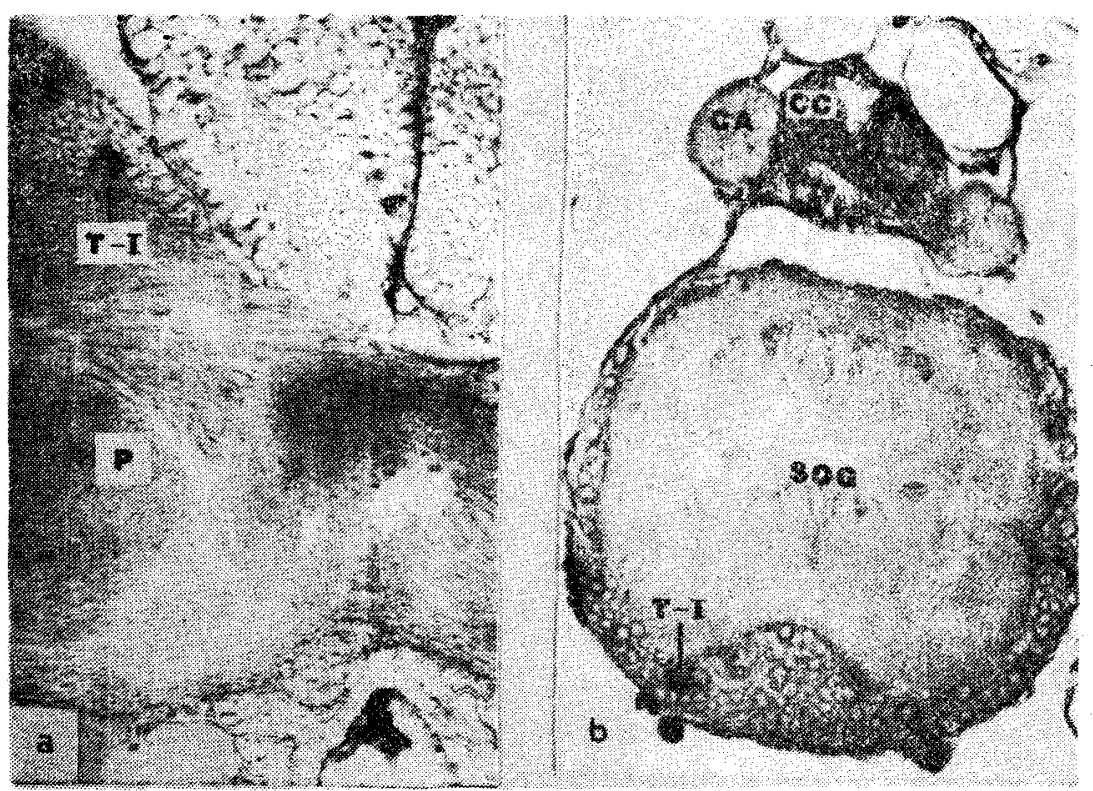

Fig. 3. Type-I neurosecretory cells in the lateral of the protocerebrum (a) $25 x$. and central of the suboesophageal ganglion (b) 25x. Note the CC-CA coplex. 


\section{Type-II Neurosecretory Cells}

The cytoplasm of these cells was stained light green with paraldehyde fuchsin. The scattering of the granules, stained light purple, in the cytoplasm of these cells was homogenous; however, it was observed only by high magnification (Fig. 4). This type of cells were observed in median, lateral and ventral of the protocerebruf, and in the ventral and the lateral of the suboesophageal ganglion (Fig. 2c, 4, 5).

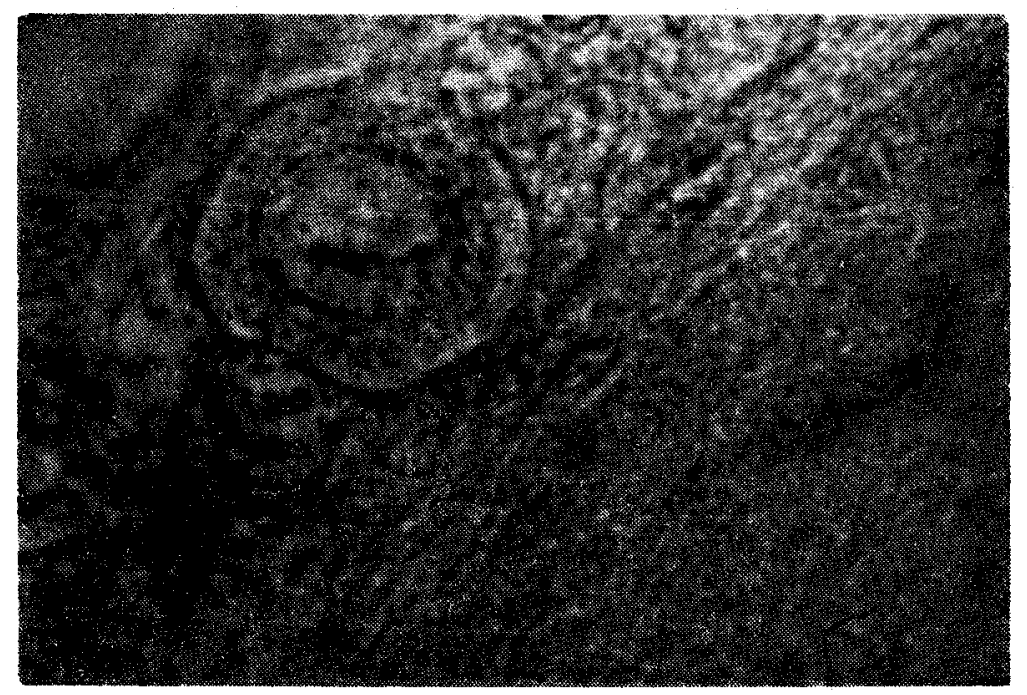

Fig. 4. Type-II neurosecretory cell in the pars intercerebralis of the protocerebrum. 1000x.

\section{Type-III Neurosecretory Cells}

The cytoplasm of these cells was clearly stained brilliant dark green with paraldehyde fuchsin. They were located in both lateral of the protocerebrum, just above the brain tissue and a little bit deeper than the type-I neurosecretory cells were. This type of neurosecretory cells in contrast to other types were present as groups containing 8-10 cells adjacent to each other taking other types of cells among them (Fig. 5).

Nervi Corporis Cardiaci

The neurosecretory cells of $P$. turionellae are unipolar nerve cells. The fact that the granules, also present in the axons of these cells, stained dark purple in the cytoplasm of Type-I neurosecretory cells with paraldehyde fuchsin makes the observation of the axons much easier (Fig. 2a). The axons coming from the Type-I median neurosecretory 


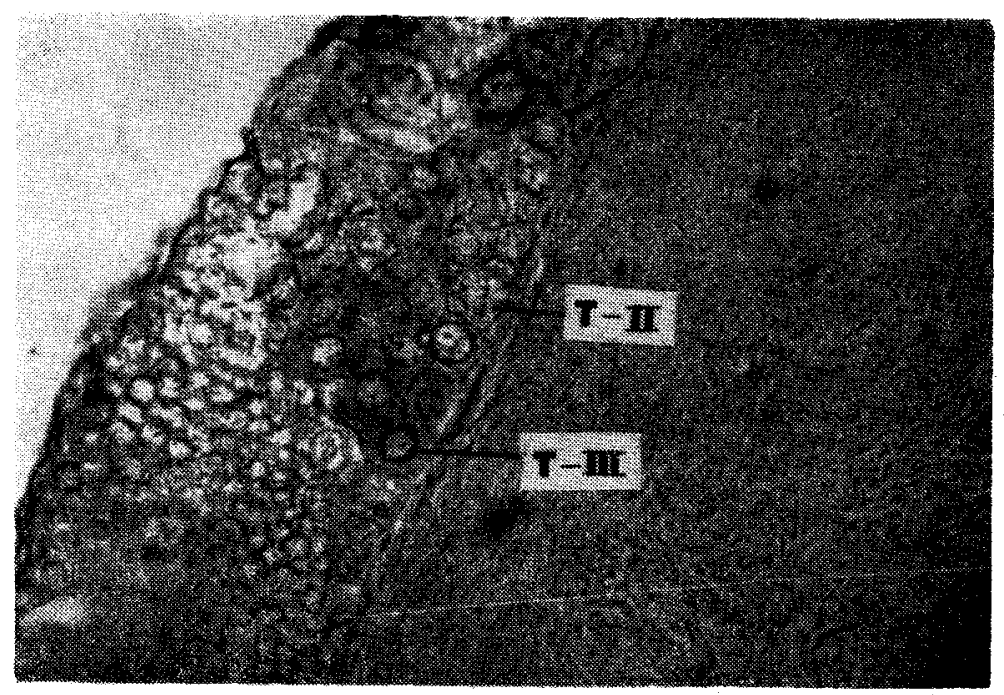

Fig. 5. Type-II and Type-III neurosecretory cells in the lateral of the protocerebrum. 130x.

cells become narrower towards the ventral of the protocerebrum. These narrowed axons procede as two thin lines towards the ventral part. These two clusters of axons are observed to mix each other at the ventral of the protocerebrum (Fig. 6a). This part is swollen due to large amount of dark purple stained granules and it is quite difficult to decide whether the axon clusters cross each other or not due to its dark staining (Fig. 6a). The distance which nervi corporis cardiaci cover in the brain becomes much clearer in sagittal sections. In these sections the axons coming from the Type-I median neurosccretory cells are seen to cross the brain by forming an arc (Fig. 6b). It is observed that when the Type-I median neurosecretory cells consist abundant amount of neurosecretory material, there also observed abundant neurosecretory material in the nervi corporis cardiaci. In some preparetes there observed granules both out and inside the nervi coiporis cardiaci in the brain tissue. The shapes and the sizes of these granules, present in the nervi corporis cardiaci and stained the same colour like Type-I neurosecretory cells, are different. There observed large granules as well as immeasurable small ones. The diameter of the largest granule was measured to be 5,93 micron.

Corpora Cardiaca and Corpora Allata

Corpora cardiaca are connected to the brain with the nervi corporis cardiaci just ventro-posterior to it. The axons get sparsed and fill the 

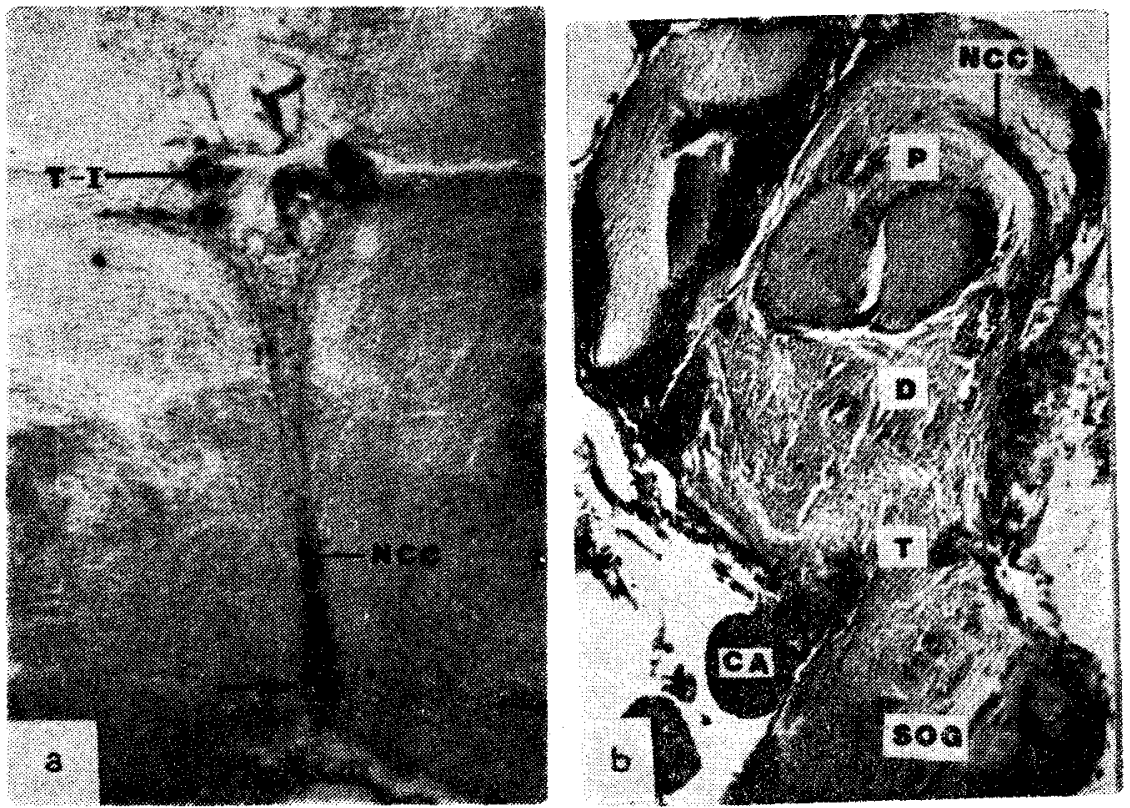

Fig. 6. Pars intercerebralis of protocerebrum, showing two groups of median Type-II neurosecretory cells. Arrow indicates the mixing of two axons elusters and it is quite difficult to decide whether the axons clusters across each other or not $100(\mathrm{a}) . \mathrm{x}$. The NCC pathway in sagittal section of the brain (b). $100 \mathrm{x}$.

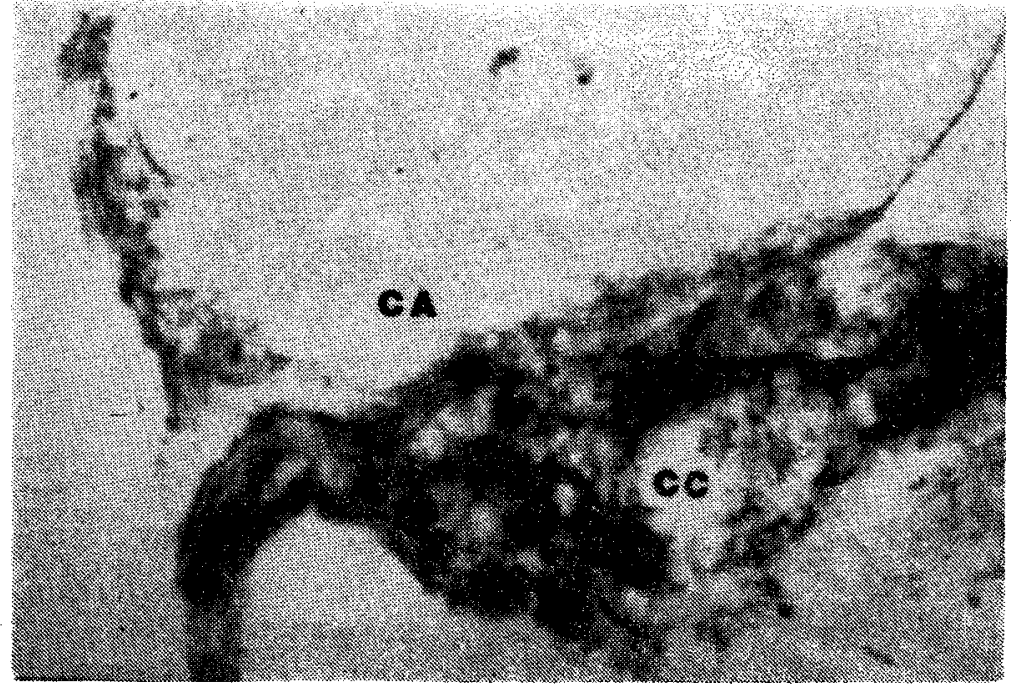

Fig. 7. The neurosecretory material within the posterior corpus cardiacum. $670 \mathrm{x}$. 
center of the gland after they leave the nervi corporis cardiaci and enter the corpora cardiaca. The material, stained dark purple with paraldehyde fuchsin staining, consists of big and small granules which do not fill the gland. The granules are generally located in the anterior of the corpora cardiaca, and posierior of the corpora cardiaca where it is connected to the corpora allata (Fig. 7 ) and in the dorsal surface of the corpora cardiaca looking towards the aorta (Fig. 8). The corpora cardiaca are stuck to the ventro-medial part of the corpora cardiaca (Fig. 1,8). Each gland consists of about $16-18$ cells. In some sections the cell boundary is clearly visible. The cell nuclei are similar to cell structure and have oval or spherical shape. There are neurosecretory granules similar to ones observed in Type-I neurosecretory cells in the middle of the gland (Fig. 8). The nervous connection of the corpus allatum with the corpus cardiacum is observable in some sections.

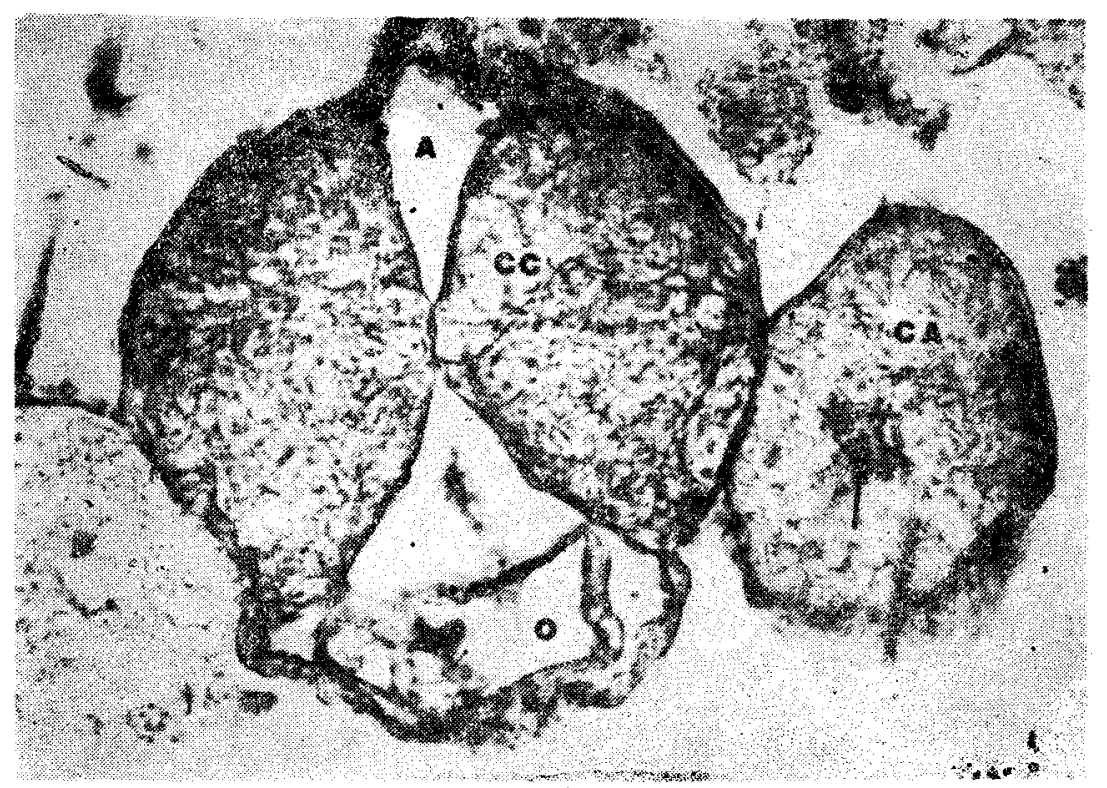

Fig. 8. Sagittal section of the corpus allatum that demonstrates the presence of PF-stained granules (arrow) within the corpus allatum. $400 x$.

\section{DISCUSSION}

The brains of mature $P$. turionellae females and males are like the general plan of the brains in other pterygote insects. The merged situation of the tritocerebrum and the suboesophageal ganglion in $P$. turio- 
nellae was also demonstrated in some insects (NAYAR, 1955; GANAGARAJAH, 1965; HOFFMANN, 1970; SINGH and SRIVASTAVA, 1974; CREDLAND and SCALES, 1976). Thomsen (1954) explained the histology and the morphology of the endocrine organs in seven different species of Hymenoptera. This worker stated among the species he studied, that only the hypocerebral ganglion of Megachile cinta was formed by the accumulation of several cells. The histological and morphological structures of the brain and the retrocerebral endocrine glands of $P$. turionellae show a great similarity to those of Hymenoptera species studied by Thomsen (1954).

Total staining method was used to show the location of the endocrine centers by staining the secretory material in the neurosecretory cells and their axons (DOGRA, and TANDAN, 1964; DOGRA, 1967; AWASTHI, 1972). But when this method was applied to $P$. turionellae, the median and lateral neurosecretory cells and their axons in the brain were not seen. This may be either due to the difference of the histochemical nature of secretory material in different insect species, or due to the fact that in some insects the neurosecretory cells and their axons are covered with a astrong tissue impermeable to the stain (ARVY and GABE, 1962).

The chrome haematoxylin phloxine and the paraldehyde fuchsin staining techniques developed by Gomori $(1941,1950)$ have been the most frequently used techniques in order to show the neurosecretory cells of insects. In the opinion of some workers, the chrome haematoxylin phloxine was not very successful in the segregation of various types of neurosecretory cells in some insects (ARVY and GABE, 1962; JOHNSON, 1963; AWASTHI, 1976; CREDLAND and SCALES, 1976; ÖZLÜK, 1991). When both techniques were applied to $P$. turionellae, only satisfactory results were obtained with paraldehyde fuchsin. Thomsen (1954) used only chroma haematoxylin phloxine in his studies, but he stated that this staining technique was not very successful in staining the neurosecretory material. The neurosecrevory cells in the brain of $P$. turionellae were stained in different colour with the paraldehyde fuchsin. The Type-I neurosecretory cells of $P$. turionellae are like the A-Type of Nebria brevicollis (GANAGARAJAH, 1965), Dysdercus koenigii (DOGRA, 1967), Labidura riparia (AWASTHI, 1976), Jamaicana flava PEACOCK and ANSTEE, 1977) and the Type-I of Balps mucroanta (FLETCHER, 1969) in respect of their stainability with the paraldehyde fuchsin. In some sections of $P$. turionellae there observed one, two or 
three Type-I neurosecretory cells in the lateral of the protocerebrum and in the ventral of the suboesophageal ganglion respectively. The $\mathrm{A}-\mathrm{Ty}-$ pe neurosecretory cells, which show the same stainability as in the Type-I cells of $P$. turionellae, were shown to be located in the same sites of the brain of Pterostichus nigrita in the same numbers (HOFFMANN, 1970). In addition to this, Fletcher (1969), Awasthi (1973), Cuedland and Scales (1976) stated that there were the same type of cells in the suboesophageal ganglion of B. mucronata, Metochus uniguttatus, and Chironomus riparius.

The Type-II neurosecretory cells of $P$. turionellae are similar the Btype neurosecretory cells of $P$. nigrita (HOFFMANN, 1970) and C-Type of $J$. flava (PEACOCK and ANSTEE, 1977) in regard to their stainability with paraldehyde fuchsin. The fact that the granules in the Type-I cells are observed in very small numbers in same cells of $P$. turionellae makes one think that these celis are converted to Type-II neurosecretory cells. The reurosecretory cells in the median of the protocerebrum of Synagris calida (THOMSEN, 1954) are similar to Type-I and Type-II neurosecretory cells of $P$. turionellae. But, Thomsen (1954) did not define them as different cell types and he claimed that they might be the various stage of secretory activity of the same cells.

The Type-III cells of P.turionellae, located in the lateral of the protocerebrum, whose cytoplasm was stained brillant dark green with paraldehyde fuchsin, are similar to the Type-II neurosecretory cells of $D$. koenigii (DOGRA, 1967), P. nigrita (HOFFMANN, 1970), L. riparia (AWASTHT, 1975) and $E$. annulipes (AWASTIII, 1976) with respect to their stainability. Ganagarajah (1965) did not encounter the lateral neurosecretory cells although he used the same staining technique. Thomsen (1954) stated in his study, in which he examined seven different species of Hymenoptera, that there were no such cells. But he used the chrome hamatoxylin phloxine, which is not very satisfactory as a staining method (JOHNSON, 1963; AWASTHI, 1976; OZLÜK, 1991). However, the Type-III cells of $P$. turionellae were clearly different cells from the Type-I and Type-II neurosecretory cells, because of their different staining characteristic with the paraldehyde fuchsin.

The nervi corporis cardiaci-I and II axons coming from the median and lateral neurosecretory cells of the protocerebrum were observed in many insects (GANAGARAJAH, 1965; HOFFMANN, 1970; AWASTHI, 1976; OZLUK, 1991). The fact that there is no nervi corporis cardiaciII in $P$. turinoellae and the situation in other studied Hymenoptera 
(THOMSEN, 1954) show great resemblance. Whether the nervi corporis cardiaci cross each other in the brain of $P$. turionellae or not is not clear. These contrasting situations were observed in some other insects as well (THOMSEN, 1954; GANAGARAJAH, 1965).

It was stated that the neurosecretory materia! secreted by the neurosecretiry cells of the protocerebrum was stored in different neurohaemal organs and given into haemolenph. Although the corpora cardiaca were generally shown as a the neurohaemal organ (ARVY and GABE, 1962; FRIEDEL and LOUGHTON, 1980) some workers claimed the aorta wall as the neurogaemal organ (AWASTHI, 1976; JUBERTHIE and CAUSSANEL, 1980). Awasthi (1973) showed the aorta wall as neurohaemal organ in $M$. uniguttatus and also stated that some of the neurosecretory material passed from nervi corporis directly into haemolenph without going to neurohaemal organ. It was thought that the neurohaemal organ in $P$. turionellae was corpora cardiaca and some of the neurosecretory material directly passed into haemolenph because of the fact that the amount of the neurosecretory material in the corpora cardiaca was never as abundant as in the nervi corporis cardiaci.

\section{ACKNOWLEDGEMENT}

This is the Ph. D. thesis of the author. I would like to thank to Prof. Dr. Süheyla Küçükekşi for proposing this subject of research and to Prof. Dr. Sevine Karol for enabling me to carry out the research, and the recievers for valuable comments. I would also like to thank to Dr. Hakkı Sayar for his kind assistance.

\section{ABBREVIATIONS FOR FIGURES AND TEXT}

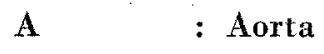

CA : Corpora allata

CC : Corpora cardiaca

D : Deutocerebrum

NCG : Nervi corporis cardiaci

O : Oesophagus

$\mathrm{P}:$ : Protocerebrum

SOG : Suboesophageal ganglion

$\mathrm{T} \quad \cdots \quad$ : Tritocerebrum

T-I : Type-I neurosecretory cells

T-II : Type-II neurosecretory cells

T-III : Type-III neurosecretory cells 


\section{REFERENCES}

ARVY, L. and M. GABE, 1962. Histochemistry of the neurosecretory product of the pars intercerebralis of pterygote insects. Neurosecretion by HELLER, H. and R. CLARK, 331-334.

AWASTHI, V.B., 1972. Neurosectorery system of the adult flesh-fly Sarcophngn ruficornis F. (DIPTERA: SARCOPHAGIDAE). J. Insect Morphol. and Embryol., 1 (2): 133-140.

, 1973. Neurosecretory system and retrocerebral endocrine glands of Metochus uniguttatus THUNB. (HETEROPTERA: LYGAEIDAE). J. Insect Morphol. and Embryol., 2 (1): $1-12$.

- - - 1975. Neurosecretory system of earwig $L a b$ idura riparia, and the role of the aorta as a neurohaemal organ. J. Insect Physiol., 21: 1713-1719.

- 1976. Neurosecretory cells and aorta as a neurohaemal organ in the aerwig, Euborellia annulipes LUCAS (DERMAPTERA: LABIDURIDAE). J. Insect Morphol. and Embryol., 5 (4/5): $253-260$.

CREDLAND, P.F. and M.D.C. SCALES. 1976. The neurosecretory cells of the brain and suboesophageal ganglion of Chironomus riparius. J. Insect Physiol., 11: 1325-1330

DELPHIN, F., 1966 A critique of the CHP and PF techniques of Gomori, Union of Purma, J. Life Sci., Congress. March 26: 22-25.

DOGRA, G.S. and K.B. TANDAN, 1964. Adaptation of certain histological techniques for in situ demonstration of the neuroendocrine system of insect and other animals. Quarts. J. Mic. Sci., 105: 445-446

DOGRA, G.S., 1967. Studies on the neurosecretory system and the functional significance of NSM in the aorta wall of the bug, Dysdercus koenigii. J. Insect Physiol., 13: 1895-1906

FLETCHER, B.S., 1969. The diversity of cell types in the neurosecretory system of the beetle Balps mucronata. J. Insect Physiol., 15: 119-134.

FRIEDEL, T and B.G. LOUGHTON, 1980. Neurosecretory protein synthesis in relation to starvation and feeding in adult male Locusta migratoriu. J. Insect Physiol., 26: 33-37.

GANAGARAJAH, M., 1965. The neuroendocrine coplex of adult Nebria brevicollis (F.) and its relation to reproduction. J. Insect Physiol., 11: 1377-1387.

GOMORI, G., 1941. Observation with differential stains on human ilets of langerhans. Amer. J. Path., 17: 395-406.

GONORI, G., 1950. Aldehyde fuchsin a new stain for elastic tissue. Amer. J. Clin. Path., 20: $325-329$.

HIGHNAM, K.C., 1961. The histology of the neurosecretory system of the adult female desert locust Schistocerca gregaria QUART. J. Mic. Sci., 102:27-38.

HOFFMANN, H.J., 1970. Neuro-endocrine control of diapanse and ö̈cyte maturation in the beetle, Pterostichus nigrita. J. Insect Physiol., 16: 629-642

JOHNSON, B., 1963. A histologieal study of neurosecretion in aphids. J. Inseet Physiol., 9:727739 
JEBERTHIE, C. and C. CAUSSANEL, 1980. Release of brain neurosecretory products from the neurohaemal part of the aorta during egg-laying and egg-care in Labdiura riparia (INSECTA: DERMAPTERA). J. Insect Physio!., 26: 427-429

KHAN, M.A., H.M. ROMBERG.PRIVE, and H. SCHOONEVELD, 1984. Innervation of the corpus allatum in the Colorado Potato Beetle as revealed hy retrograde diffusion with horseradish peroxidase. Gen. Comp. Endocrinol., 55:66-73.

NAYAR, K.K., 1955. Studies on the neurosecretory system of Iphita limbata STAL. I. Distribution and structure of the neurosecretory cells of the nerve ring. Bioll. Bull., 112: 296-307

ÖZLÜK, A., 1991. Brain neturosecretory system and retrocerebral endocrine glands of A. bicolor (THUNB) (ORTHOPTERA: ACRIDIDAE). Commun. Fac. Sei., Univ. Ank. Ser. C., $9: 17-31$.

PEACOCK, A. and J.H. ANSTEE, 1977. Neuroendocrine comlex of Jamaicana flava (CAVDELL) (ORTHOPTERA: TETTIGONIIDAE). J. Insect Morphol. and Embryol., 6 (1): $1-16)$

ROSEN, D., 1986. Biological control. Comprehensive Insect Physiology Biochemistry and Pharmacology by KERKUT, G.A. and L.T. GILBERT., 12: 413-464

SINGH, Y.N. and U.S. SRIVASTAVA, 1974. Structure and metamorphic changes in the brain of castor silk moth, Philosamia ricini HUTT. (LEPIDOPTERA: SATURNIIDAE). J. Insect Playsiol., 3 (3/4): 371-384.

STRONG, L., 1965a. The relationships between the brain, corpora allata, and oöcyte growth in the Central American Locust, Schitsocerca sp., I. The cerebral neurosecretory system, the corpora allata, and the oöcyte growth. J. Insect Physiol., 11:135-146

THOMSEN, M., 1954. Neurosecretion in some Hymenoptera., Dan. Biol. Skr., 7:1-24. 